\title{
FACTORS THAT AFFECT THE RETENTION OF MANAGERIAL AND SPECIALIST STAFF: AN EXPLORATORY STUDY OF AN EMPLOYEE COMMITMENT MODEL
}

\author{
KOOS KOTZÉ \\ GERT ROODT \\ jck@dotmail.co.za \\ Leadership in Performance and Change Programme \\ Department of Human Resources Management \\ University of Johannesburg
}

\begin{abstract}
A study about the factors affecting the retention of managerial and specialist staff was conducted amongst the 120 highest paid employees of two banks. The response rate was $86 \%$. The study investigated the Veldsman Employee Commitment model. The study also explored whether retention factor differences exist amongst biographical groupings. Various differences were identified between previously disadvantaged individuals (PDIs) and non-PDIs, male and female, service tenure groups and age groups.
\end{abstract}

\section{OPSOMMING}

' $\mathrm{n}$ Studie is gedoen insake die faktore wat retensie van bestuur- en spesialispersoneel affekteer. Dit is gedoen onder die 120 hoogste betaalde bestuurs- en spesialispersoneel van twee banke. $86 \%$ van die steekproef het reageer. Die studie het Veldsman se "Employee Commitment" model ondersoek. Verdere ondersoek is gedoen om te bepaal of retensiefaktore beduidend verskil tussen biografiese groeperinge. Beduidende verskille is geidentifiseer tussen voormalige benadeelde individue (VBIe) en nie-VBIe, mans en vroue, diensjare groepe en ouderdomsgroepe.

The 'war for talent' is an international phenomenon (Hay, 2001). The demand for and retention of talent are therefore not challenges unique to South African employers. In South Africa, however, these challenges are aggravated by three additional factors, namely 1) the emigration of skilled people that has and still is taking place at an alarming rate (Frost, 2002); (2) the relative scarcity of specialist and managerial employees due to an oversupply of unskilled labour and an under-supply of skilled labour (Frost, 2002); and (3), a national drive to address employment equity, which is fuelling the war for talent among people from designated groups.

Employers are left with two options to succeed in the South African war for talent: Option 1 is to become and remain an employer of choice - thus becoming a "talent magnet" that is able to attract and retain people with the required profile (Johnson, 2002); and Option 2 is to develop, retain and efficiently utilise the employer's existing talent pool. As far as retention is concerned, the employer has to explore and then manage the factors or attributes that influence such skilled or talented employees to either "stay" or "leave" (Dibble, 1999).

This study focuses on the second option, and more specifically on retention.

\begin{abstract}
Aims of the study
The primary objective of the study is to investigate the major factors that affect the retention of specialist and managerial staff in two South African banks. The secondary objective is to investigate whether differences exist between (a) the previously disadvantaged individuals and non- previously disadvantaged individuals, (b) males and females, (c) age groups and (d) service tenure groups in respect of factors contributing to staff turnover.
\end{abstract}

\section{National and international trends in staff turnover and retention}

The P-E Corporate Service's international biannual survey of more than 800 companies employing 1,5 million people shows that national staff turnover averaged $13 \%$ over the past four years, compared with 10\% in 1998 (Westcott, 2003). The survey also reported that the main reason for leaving an employer was

Requests for copies should be addressed to: G Roodt, gertr@uj.ac.za the prospect of better pay and better working conditions. Among skilled staff, $23 \%$ of those who resigned did so for better pay, 5 percentage points more than in 2001. This accounted for about $19 \%$ of staff resigning at lower levels - about 6 percentage points lower than in 2001. The turnover was at its highest among skilled clerical, secretarial, financial and administrative staff, reaching $20 \%$. The figure for management and specialist staff was about $15 \%$, with $10 \%$ for senior management.

The shifts in retention and turnover experienced in the South African labour market are also experienced internationally. According to Hay (2002), holding onto jobs was a priority in the late 1980s and early 1990s as employees were laid off in their droves. This has since all changed. Employee turnover has increased by $25 \%$ in the last five years. Hay (2002) strengthens this point by referring to an international survey spanning over 50 countries and 330 companies, where one-third of employees plan to resign from their jobs within the next two years. It is clear from the above that retention is becoming an increasing challenge, locally and internationally.

In the Markinor South African Employee relationship survey (Markinor, 2003) employees were asked to rate factors that they presume affect commitment. In descending order of influence, the factors influencing commitment to the organisation included fairness at work, the reputation of the company, concern for employees, trust in employees, day-to-day satisfaction, job definition, a sense of achievement, work resources, communication, appreciation of ideas and union attitude.

\section{Retention of staff is an issue of importance}

Taylor (2002) quotes from the Towers Perrin survey among HR professionals in the UK where $75 \%$ of the respondents believe that retention is their number one people-related issue. Ninetytwo percent of respondents were of the opinion that retention is increasing in importance. Taylor (2002) supports this statement by mentioning US workers who typically hold 5,6 different fulltime jobs between the ages of 18 to 24 .

Compounding the problem is the continued erosion of employee loyalty. According to Taylor (2002), the Generation X employees (those born between 1961 and 1981) have different values than the previous generation source. They believe that security is tied 
more to career than to a company. Jobs are therefore seen as stepping-stones to the next opportunity. This attitude can also be seen as a reaction to a loss in company loyalty.

Retention and staff turnover are issues of importance because they impact on an organisation in several ways. The research of Ahlrichs (2000) highlights the very high and often underestimated costs of turnover of key staff for employers (also compare Roodt \& Bothma, 1997). The visible turnover costs are items such as leave capitalization, recruitment costs, reference checks, security clearance, temporary worker costs, relocation costs, formal training costs and induction expenses. Invisible costs include increased HR and payroll administration, loss of productivity, transition meetings and informal training. Hidden costs such as missed deadlines, loss of organisational knowledge, lower morale due to overwork, clients' impact and chain reaction turnover. Another turnover impact for the organisation is the fact that long-tenured employees develop personal relations with customers. These relations are the foundation for a reenforcing cycle of positive interactions between employees and customers. Staff retention therefore has a positive effect on good customer relations and ultimately profitability (Roland, Rust, Stewart \& Pielack, 1996). Demotivated remaining staff is another outcome of staff turnover. Losing good employees is also costly in terms of the impact it has on company morale. Those that remain may often feel demotivated or disheartened, resulting in a drop in productivity and job satisfaction. If staff members witness the new job opportunities being snapped up by their colleagues, they could also follow suit.

These latter expenses, although more difficult to quantify, are also costly (Hay, 2001).

Although there may be other factors that affect retention, the factors as indicated by the Veldsman model will be investigated for the purposes of this study.

A model to illustrate the antecedents of retention

Veldsman (2003) proposed a model to explain the relationship of various factors that affect the propensity of an employee to stay or leave an organisation. This model is given in Figure 1.

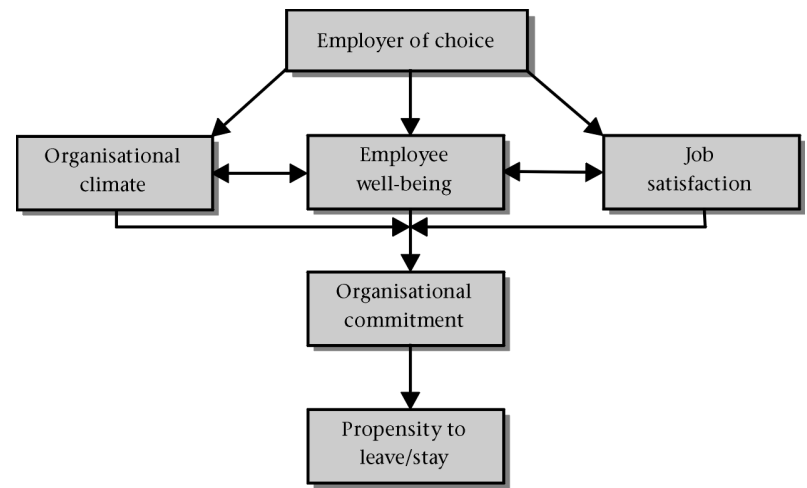

Figure 1: Veldman's employee commitment model

According to Figure 1 an individual in the first instance has certain views regarding his/her organisation as an Employer of Choice (EoC) which affects his/her decision to join and stay with the company. The propensity to stay or to leave is further affected by Organisational climate and culture, Job Satisfaction, and Employee Well-being. Organisational Climate and culture reflects how the individual engages with the macro work setting. Job Satisfaction indicates the micro (or immediate) work setting engagement of the employee. Employee Wellbeing is situated between Organisational Climate and Job Satisfaction. This positioning indicates the positive and/or negative responses of the employee to his/her total work setting, i.e. the macro and micro work settings, which is reflective of his/her internal experiences of his/her work engagement.
The propensity to stay or leave according to the Veldsman model in Figure 1 is moderated by the individual's mobility (the ability to pursue and find alternative employment) and the prevailing market conditions facing the individual (such as a favourable or unfavourable supply/demand for labour or the prevailing economic climate). Figure 2 describes the influence of mobility and market or industry conditions on the propensity to leave or stay (Veldsman, 2003).

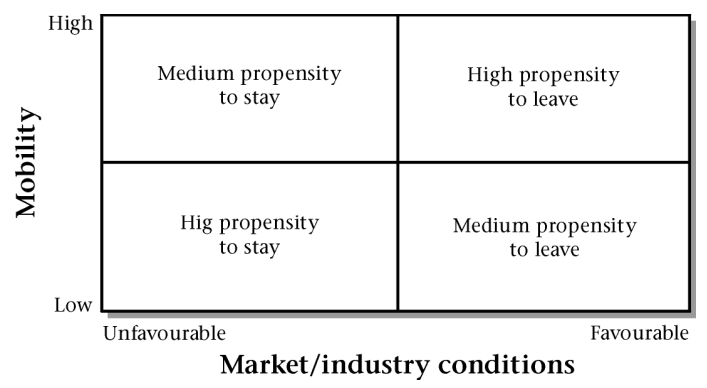

Figure 2: Effect of mobility and market conditions on the propensity to stay or leave

Factors that affect the retention of employees

The factors that affect retention of employees have to be managed - and must therefore be identified. Such factors are clustered into three categories as described in the Veldsman model: factors pertaining to organisational climate and culture; factors pertaining to job satisfaction and factors pertaining to employee well-being.

\section{Factors pertaining to organisational climate}

Organisational climate is defined as an enduring characteristic of an organisation which embodies the members' collective perceptions about their organisation with respect to dimensions such as trust, cohesiveness, support, recognition, innovation and fairness. It also reflects the prevalent norms, values and attitudes and the organisation's culture (Moran \& Volkwein, 1992, p. 20). The following studies have linked retention to organisational climate:

- Employees are more likely to leave if they perceive a lack of clear direction on the part of management. An international survey spanning 50 countries and 330 companies revealed that $74 \%$ of dissatisfied employees feel that their company has no clear sense of direction, compared to $43 \%$ of satisfied employees. It would appear that companies are less adept at marketing themselves to their employees than they are at selling the company to other stakeholders (Hay, 2002).

- Level of control over work environment: Lok and Crawford (1999) found a significant positive correlation between commitment and the level of control over the work environment. Control in this context refers to the employee's freedom or ability to influence or manipulate the work environment.

- Lok and Crawford (1999) also found a significant positive correlation between commitment and innovative and supportive subcultures. In this context, an organisational subculture refers to the culture in a section, team or department, which is often different to the greater organisational culture. In the same study, a negative correlation was found between commitment and a bureaucratic subculture. The Markinor (2003) study also pointed out that commitment levels to a team or department are stronger than to the company, strengthening the argument that "employees quit a boss, not a company".

- Employees' reaction to "the war-for-talent mindset": Demby (2002) reported that many top-performing companies are obsessed with talent and are endlessly recruiting and dismissing as many top performers as they can. Many companies believe that bringing in people from outside the company is necessary for high performance. An unintended 
negative consequence of this mindset was that newly recruited people, supposedly with the sought-after talent, were viewed as being superior to existing staff in the company. As a result, the "institutional type of employee" (the loyal career type who wants to stay in the company) started to believe that the only way to get ahead was to leave - to move from company to company. In this sense, "being loyal" became negative.

\section{Factors pertaining to job satisfaction}

Job satisfaction is a result of employees' perceptions of how well their jobs provide in those qualities that they perceive as important (Luthans, 1998, p. 44). A strong correlation, and in fact a causal relationship between job satisfaction, employee commitment and retention, has been established in several studies to date, as reported by Roland et al (1996). The following specific factors pertain to job satisfaction and its relationship to retention:

- Udo and Tor-Guimaraes (1997) found that significant indirect influences on the intention to stay were job satisfaction, job involvement, task characteristics and role stressors.

- The second-highest factor contributing to high turnover according to Hay's international study (2002) is that employees are "unhappy with their boss". In fact, $74 \%$ of those who planned to stay were happy with their managers, compared to $41 \%$ of those planning to leave.

- In a landmark study by the Gallup Organisation that includes interviews with 1 million employees and 80000 managers, it emerged that people leave managers, not companies. This suggests that if a turnover problem exists, first look at the organisation's managers (Taylor, 2002).

- Leadership and managerial strategy: The link between leadership and commitment is evident in the work of Brewer (1993). Here, employees' commitment was examined in relation to the level of consent to, and conflict with, managerial strategy. In Brewer's model of commitment, although managerial strategy is not the same as leadership, the attributes and skills required in leadership could be seen as an essential part of managerial strategy. In the research of Lok and Crawford (1999), a consideration leadership style was found to have a greater influence on commitment and job satisfaction than a taskorientated leadership style.

- Satisfaction of higher-order needs: The study of Lok and Crawford (1999) confirmed the strong positive correlation between commitment and higher-order needs, or intrinsic factors as per Mazlow's Hierarchy of Needs Theory and Herzberg's Theory of Motivation. Examples of higher-order needs as per Lok and Crawford's study (1999) referred to the level of control over the working environment, the amount of interaction, acceptance by co-workers, the level of professionalism, praise received from colleagues and leader as well as feedback.

- Asymmetric information: Sigler (1999) stated that insufficient information on and communication about the employee's performance may complicate the employer's endeavour to retain productive employees. Without adequate information, an employer may not be able to distinguish between productive and non-productive employees. Employees often take credit for successes and deflect failures to other employees. Also, poor communication can lead to a situation where the manager does not know what information to ask the employee and the employee does not know what to provide. Therefore, productive workers cannot distinguish themselves from non-productive workers and are not rewarded accordingly.

\section{Factors pertaining to employee well-being}

Warr (1990) described affective well-being as the emotional state of employees within their total work setting as being either predominantly negative or positive on 3 principal axes: (a) anxious - contented, (b) enthusiastic - depressed and (c) pleased - displeased.
Having established the relationship between employee satisfaction and retention in the previous section, it is important to note that Roland et al (1996) found that employee satisfaction is largely driven by satisfaction with managerial processes related to employee well-being. These processes include supervision, benefits, work design and work environment.

The following specific factors pertain to employee well-being and its relationship to retention:

- Skills and talent development: This proved to be the most significant retention factor in an international study, as reported by Hay (2002). Another significant factor that emerged from this study is managers who fail to take an interest in staff's career development. Both these factors were found to have a profound effect on the emotional well-being of employees in their work situation. Closely associated with skills and talent development is the opportunity to learn new skills. According to Hay's international study (Hay, 2002) only $38 \%$ of those planning to leave were satisfied with the current opportunities to learn new skills. The Markinor South African employee relations survey (Markinor, 2003) also pointed out that development of a long-term career is a major driver of employee loyalty. Therefore, many employees feel trapped in a narrow job function with little scope for development. This trapped feeling was also found to have a profound effect on the emotional well-being of employees.

- Advancement opportunities: Hay's study (2002) also revealed that only $22 \%$ of employees planning to leave were satisfied with advancement opportunities. This dissatisfaction was found to be an important factor in the emotional wellbeing of staff.

- The P-E Corporate survey in which 800 South African companies participated, reported that the main reason for leaving an employer was the prospect of better pay and better working conditions. Amongst skilled staff, $23 \%$ of those who quit left for better pay. This accounted for about 19\% of staff resigning at lower levels (Westcott, 2003).

- According to a study by Walker Information spanning 31 countries, what employees want (i.e. the top drivers for employee loyalty) is fair treatment, care/concern and trust, and better communication. The South African leg of this survey revealed the same result (Markinor, 2003). Yet, as reported by Taylor (2002), a retention study by the Society of Human Resource Management shows that what employers give employees instead, are better benefits and more competitive compensation - i.e. commodities. This is according to Taylor (2002) a problem of alignment - not giving what employees want.

In the previous sections, the link between propensity to stay or leave on the one hand, and organisation climate/culture, job satisfaction and employee well-being on the other hand, was illustrated.

\section{The link between employee commitment and his/her} propensity to stay or leave

In this section the link between employee commitment and their propensity to stay or leave will be addressed.

Durkin and Bennett (1999, p. 124) defined employee commitment as a mindset that ties the individual to the organisation. The authors distinguished between three levels of employee commitment: (1) Internalised commitment: The employee adopts specific behaviours and attitudes because their contents are congruent with the individual's value system; (2) Identification commitment: The employee adopts attitudes and behaviour in order to gain association with a valuable third party and (3) Compliance commitment: The employee adopts specific patterns of behaviour and attitudes in return for specific rewards.

Employee commitment and employees' propensity to stay or leave have been found to be negatively related to labour 
turnover in the studies of Cotton and Tuttle (1986) and Clegg (1983). Udo and Tor-Guimaraes (1997) found significant correlations between organisational commitment and intention to stay (correlation of 0,33 ) amongst 216 plant managers. The correlation between job satisfaction and organisational commitment also proved to be strong $(0,46)$.

Durkin and Bennett (1999) reported studies where significant negative correlations were found between internalised commitment and turnover, as well as a positive correlation with longer tenure intentions.

However, an interesting dynamic was found in the research of Durkin and Bennett (1999). They found a low intent to leave was related to high levels of identification commitment, and low levels of internalized commitment. The low level of internalized commitment was the result of significant changes in the case organisation. The employees did not accept these changes well. However, staff members' high level of identification commitment more than compensated for the potential increase in a propensity to leave. Identification commitment therefore seems to be a powerful retention factor, which supports the rationale of employers to strive to become an "employer of choice".

Linking employer-of-choice status with the employees' propensity to stay or leave

Ahlrichs (2000, p. 37) described an employer of choice (EoC) as a company that, because of its status and reputation, is always the first choice (or at least on the shortlist) of high quality candidates. These companies outperform their competition in attracting and retaining talented people. In the Veldsman model, the EoC status of an organisation would attract or distract the employee to join the company. EoC companies score high in the following dimensions according to Ahlrichs (2000): Comparative high compensation contingent on performance; sensitivity to work, health and family needs; good growth opportunities; job security; high level of pride in work and company (this could be linked to identification commitment); openness, good communication; fairness; reduced status distinctions and barriers; camaraderie and friendliness; selective hiring of new personnel - ensuring that talented, dedicated staff members with good interpersonal skills are hired.

The research of Herman and Goya (2000) added to this list by finding that an EoC provides career growth, opportunities, a challenging work environment and meaningful work, involvement and the opportunity to make a difference - all of these being more important than money.

All of the EoC characteristics have been dealt with in the previous sections and have been linked to the propensity of employees to stay or leave.

\section{RESEARCH DESIGN}

\section{Research approach}

The research approach followed in this study was a quantitative, non-random field survey. The data analysis conducted was correlational and ex post facto in nature using the primary data generated by the survey. The Survey was conducted over a period of two months during 2003.

\section{Research methodology}

The research methodology followed in this study will be discussed under the following four headings:

\section{Research participants}

The 60 highest remunerated staff in each of two South African commercial banks were selected to participate in the study.
These 120 individuals represented their managerial and specialist staff, being their core talent. The 60 selected staff members of Bank A represented $9 \%$ of the bank's 660 permanent staff members, whereas the 60 selected staff of Bank B represented $7,3 \%$ of the Bank's 820 staff members. Of the 120 selected staff members, $104(86,6 \%)$ responded.

Table 1 displays a breakdown of the respondents in terms of gender, age, years of service and Previously Disadvantaged Individual (PDI) status:

TABLE 1

BIOGRAPHICAL ANALYSIS OF RESPONDENTS

\begin{tabular}{lcr}
\hline Variable & N & $\%$ \\
\hline GENDER & 47 & 45,27 \\
Male & 55 & 52,9 \\
Female & 2 & 1,9 \\
No response & 104 & 100 \\
Total & & \\
AGE & 36 & 34,6 \\
18-30 & 44 & 42,3 \\
$31-40$ & 20 & 19,2 \\
$41+$ & 4 & 3,8 \\
No response & 104 & 100 \\
Total & & \\
YEARS OF SERVICE & 46 & 44,1 \\
1-3 years & 36 & 34,6 \\
$4-9$ years & 13 & 12,5 \\
10+ & 9 & 8,7 \\
No response & 104 & 100 \\
Total & & \\
PDI STATUS & 33 & 31,3 \\
Previously disadvantaged & 69 & 1,9 \\
White male and female & 2 & 100 \\
No response & 104 & \\
Total & & \\
\hline & & \\
& &
\end{tabular}

From Table 1 it is clear that males and females are about equally represented in the sample; the majority of respondents are younger than 40 years, are less than 10 years in the employment of their organisations; and about one third are from previously disadvantaged groups.

\section{Measuring instrument}

Veldsman (2003) assisted by Geldenhuys developed the questionnaire used in this research. Veldsman granted permission for its use in this study. The Veldsman Employee Commitment Questionnaire (VEC Questionnaire) has 107 statements in six sections, based on the six theoretical dimensions of the model described in a previous section. The sections/theoretical dimensions of the questionnaire are described in Table 2:

A separate section deals with biographical information, such as race, years of service, age and gender.

The respondent agrees or disagrees with 107 statements, using a 5-point Likert scale. On the Likert scale, 1 represents a very negative response to the statement, being "strongly disagree" or "not at all", whilst 5 represents a very positive response, being "strongly agree" or "constantly".

Research procedure

Senior management's approval at both banks was obtained prior to the study. The questionnaires were distributed by the researcher to the participants. Clear instructions were provided. The purpose 
of the study and the benefits for both the participants and the two Banks involved, were explained. Participants were also given the model and theory on which the questionnaire is based. To ensure confidentiality and enhance reliability, the study was conducted anonymously. The participants placed the completed questionnaires anonymously in sealed boxes at central collection points. Strict control was maintained over the completed questionnaires. The author administered all the questionnaires to ensure consistency in the process.

TABLE 2

STRUCTURe Of THE Veldsman EMPloyee COMMITMENT QUESTIONNAIRE

\begin{tabular}{|c|c|}
\hline SECTION & DESCRIPTION OF THE DIMENSION \\
\hline Section A & ORGANISATIONAL CLIMATE \\
\hline A1: Mission \& Goals & $\begin{array}{l}\text { Management's efforts and success to have clear and } \\
\text { well communicated goals, what the organisation is } \\
\text { about and where it is going. The respondent's } \\
\text { agreement with such goals }\end{array}$ \\
\hline A2: Communication & Sufficient information flow throughout the bank \\
\hline A3: Planning & $\begin{array}{l}\text { Management's efforts and success in the planning } \\
\text { work, inter-departmental planning and job clarity as } \\
\text { a result of planning }\end{array}$ \\
\hline $\begin{array}{l}\text { A4: Coordination \& } \\
\text { control }\end{array}$ & $\begin{array}{l}\text { An organised and coordinated work environment. } \\
\text { Management in touch with ground level activities }\end{array}$ \\
\hline A5: Decision Making & $\begin{array}{l}\text { Decision making involvement and awareness of the } \\
\text { rationale of decisions in their companies }\end{array}$ \\
\hline $\begin{array}{l}\text { A6: Organisational } \\
\text { clarity }\end{array}$ & $\begin{array}{l}\text { Work gets done in organised and structured way. Jobs } \\
\text { are clearly defined and logically structured }\end{array}$ \\
\hline $\begin{array}{l}\text { A7: Performance } \\
\text { Standards }\end{array}$ & $\begin{array}{l}\text { The existence- and fairness perceptions of } \\
\text { performance standards, as well as perceived } \\
\text { recognition on performance }\end{array}$ \\
\hline $\begin{array}{l}\text { A8: Organisational } \\
\text { support }\end{array}$ & $\begin{array}{l}\text { Supports that staff would get from seniors when } \\
\text { making mistakes and management's respect for } \\
\text { staff's efforts }\end{array}$ \\
\hline A9: Team work & Efficient team functioning \\
\hline A10: Change & The efficient management of change in the bank \\
\hline A11: Diversity & $\begin{array}{l}\text { The effective management of diversity, valuing } \\
\text { diversity and equality issues }\end{array}$ \\
\hline Section B & JOB SATISFACTION \\
\hline $\begin{array}{l}\text { B1: Overall } \\
\text { satisfaction }\end{array}$ & $\begin{array}{l}\text { Overall satisfaction with bank, job, the impact that } \\
\text { job has on life and family }\end{array}$ \\
\hline B2: Skills \& abilities & $\begin{array}{l}\text { Sufficient skills to do the job, sufficient training and } \\
\text { learning opportunities }\end{array}$ \\
\hline $\begin{array}{l}\text { B3: Leadership } \\
\text { relationship with lead }\end{array}$ & $\begin{array}{l}\text { Leadership strength/competence in bank and } \\
\text { ers }\end{array}$ \\
\hline B4: Relationships & Relationship with colleagues/trust amongst colleagues \\
\hline B5: Remuneration & $\begin{array}{l}\text { Market related remuneration and fair remuneration } \\
\text { practices }\end{array}$ \\
\hline $\begin{array}{l}\text { B6: Performance } \\
\text { evaluation }\end{array}$ & $\begin{array}{l}\text { Efficient and fair feedback on performance from } \\
\text { manager }\end{array}$ \\
\hline Section C & EMPLOYER OF CHOICE \\
\hline Section D & PROPENSITY TO STAY/LEAVE \\
\hline $\begin{array}{l}\text { D1: Why I came to } \\
\text { work here }\end{array}$ & $\begin{array}{l}\text { Reasons why the respondent came to work for } \\
\text { the bank }\end{array}$ \\
\hline $\begin{array}{l}\text { D2: Why I continue } \\
\text { to work here }\end{array}$ & $\begin{array}{l}\text { Reasons why the respondent will continue working } \\
\text { at the bank }\end{array}$ \\
\hline Section $\mathrm{E}$ & $\begin{array}{l}\text { EMPLOYEE WELL-BEING: Negative and positive } \\
\text { emotions/feelings experienced lately }\end{array}$ \\
\hline Section F & $\begin{array}{l}\text { ORGANISATIONAL COMMITMENT: Care for the } \\
\text { company's future, feeling secure, would like to stay } \\
\text { with company }\end{array}$ \\
\hline
\end{tabular}

Statistical analyses

The collation of the data, the analyses thereof and the generation of results were conducted by the Statistical Consultation Service of the University of Johannesburg.
The analyses of the data were conducted in three broad phases. The first phase focused on descriptive statistics, factor analyses on two levels and determining the reliability of the theoretical dimensions in the questionnaire using iterative item analyses. On the first level, items were parcelled according to theoretical dimensions and then intercorrelated. On the second level, sub-scores were calculated on the theoretical dimensions and then intercorrelated. Due to the small number of respondents, Schepers's method for reliability analysis was applied (Schepers, 1993). The second phase focused on correlation and regression statistics. Regression analyses were conducted to establish causes of variance amongst the different theoretical constructs of the Veldsman Employee Commitment model. In the final phase, ANOVA tests, t-tests were conducted and finally Eta square coefficients were provided to determine whether differences of practical significance exist between the major biographical groupings.

\section{RESULTS}

Descriptive statistics and reliability analysis

The results of the reliability analyses on the theoretical dimensions are reported in Table 3.

TABLE 3

DESCRIPTIVE STATISTICS AND RELIABILITY ANALYSIS

\begin{tabular}{|c|c|c|c|c|c|c|c|}
\hline & $\mathbf{N}$ & $\begin{array}{l}\text { Mini- } \\
\text { mum }\end{array}$ & $\begin{array}{l}\text { Maxi- } \\
\text { mum }\end{array}$ & Mean & $\begin{array}{l}\text { Std. } \\
\text { Devia- } \\
\text { tion }\end{array}$ & $\begin{array}{c}\text { Schepers's } \\
\text { relia- } \\
\text { bility }\end{array}$ & $\begin{array}{c}\text { Cron- } \\
\text { bach } \\
\text { Alpha }\end{array}$ \\
\hline A1: Mission \& Goals & 104 & 2,50 & 5,00 & 4,0505 & 0,57070 & & 0,616 \\
\hline A2: Communication & 104 & 1,00 & 5,00 & 3,2307 & 0.77483 & & 0,731 \\
\hline A3: Planning & 104 & 1,75 & 5,00 & 3,7308 & 0,61602 & & 0,640 \\
\hline A4: Coordination & 104 & 1,33 & 5,00 & 3,1923 & 0,86984 & & 0,734 \\
\hline A5: Decision Making & 104 & 1,00 & 5,00 & 3,1603 & 0,94279 & & 0,749 \\
\hline A6: Org. clarity & 104 & 1,50 & 5,00 & 3,5721 & 0,83148 & & 0,539 \\
\hline A7: Perf. Standards & 104 & 1,17 & 5,00 & 3,3766 & 0,92607 & & 0,856 \\
\hline A8: Org. support & 103 & 1,00 & 5,00 & 3,1165 & 1,13155 & & 0,849 \\
\hline A9: Team work & 104 & 1,33 & 5,00 & 3,6442 & 0,90577 & & 0,831 \\
\hline A10: Change & 104 & 1,00 & 5,00 & 3,1058 & 0,95702 & & 0,853 \\
\hline A11: Diversity & 103 & 1,53 & 5.00 & 3,1786 & 1,05938 & & 0,930 \\
\hline $\begin{array}{l}\text { Section A: } \\
\text { ORG. CLIMATE }\end{array}$ & 102 & 1,53 & 4,90 & 3,4034 & 0,67892 & 0,966 & 0,959 \\
\hline B1: Overall satisf. & 104 & 1.00 & 5,00 & 3,6923 & 0,98060 & & 0,830 \\
\hline B2: Skills \& abilities & 104 & 2,50 & 5,00 & 3,9880 & 0,63128 & & 0,632 \\
\hline B3: Leadership & 103 & 1,63 & 5,00 & 3,9490 & 0,79548 & & 0,909 \\
\hline B4: Relationships & 103 & 1,00 & 5,00 & 3,4660 & 0,81051 & & 0,759 \\
\hline B5: Remuneration & 99 & 1,00 & 5,00 & 3,0505 & 0,96691 & & 0,862 \\
\hline B6: Perf. evaluation & 104 & 1,00 & 5,00 & 3,2404 & 1,09385 & & 0,911 \\
\hline $\begin{array}{l}\text { Section B: } \\
\text { JOB SATISFACTION }\end{array}$ & 98 & 1,70 & 4,89 & 3,6043 & 0,69816 & 0,908 & 0,945 \\
\hline $\begin{array}{l}\text { Section C: Employer } \\
\text { of Choice }\end{array}$ & 103 & 1,50 & 5,00 & 3,5825 & 0,93901 & & 0,919 \\
\hline $\begin{array}{l}\text { D1: Why I came to } \\
\text { work here }\end{array}$ & 98 & 1,67 & 5,00 & 3,6327 & 0,73103 & & 0,861 \\
\hline $\begin{array}{l}\text { D2: Why I continue } \\
\text { to work here }\end{array}$ & 97 & 1,00 & 5,00 & 3,4731 & 0,89498 & & 0,910 \\
\hline $\begin{array}{l}\text { Section D: Propen- } \\
\text { sity to stay/leave }\end{array}$ & 96 & 1,83 & 5,00 & 3,5480 & 0,78933 & 0,939 & 0,940 \\
\hline $\begin{array}{l}\text { Sect. E: Employee } \\
\text { well-being }\end{array}$ & 99 & 1,00 & 4,67 & 3,0640 & 0,92665 & & 0,918 \\
\hline $\begin{array}{l}\text { Section F: Org } \\
\text { commitment }\end{array}$ & 102 & 1,25 & 5,00 & 3,4191 & 0,84444 & & 0,738 \\
\hline
\end{tabular}


The minimum, maximum and mean scores of the 104 respondents were provided. Cronbach's Alpha reliability coefficients of $>0,7$ are considered reliable.

Correlation analysis

The intercorrelations of the different theoretical dimensions are presented in Table 4.

TABLE 4

INTERCORRELATIONS BETWEEN VARIABLES

\begin{tabular}{|c|c|c|c|c|c|c|c|}
\hline & & A & B & C & D & E & $\mathbf{F}$ \\
\hline \multirow{2}{*}{$\begin{array}{l}\text { A Organisa- } \\
\text { tion Climate }\end{array}$} & Pearson Correlation & 1 & 0,884 & 0,753 & 0,668 & 0,683 & 0,759 \\
\hline & $\mathbf{N}$ & 102 & 96 & 101 & 95 & 97 & 100 \\
\hline B Job & Pearson Correlation & 0,884 & 1 & 0,757 & 0,587 & 0,698 & 0,767 \\
\hline Satisfaction & $\mathbf{N}$ & 96 & 98 & 97 & 91 & 93 & 97 \\
\hline \multirow{2}{*}{$\begin{array}{l}\text { C Employer } \\
\text { of Choice }\end{array}$} & Pearson Correlation & 0,753 & 0,757 & 1 & 0,769 & 0,586 & 0,777 \\
\hline & $\mathbf{N}$ & 101 & 97 & 103 & 96 & 99 & 101 \\
\hline D Propensity & Pearson Correlation & 0,668 & 0,587 & 0,769 & 1 & 0,613 & 0,674 \\
\hline $\begin{array}{l}\text { to stay or } \\
\text { leave }\end{array}$ & $\mathbf{N}$ & 95 & 91 & 96 & 96 & 93 & 95 \\
\hline E Employee & Pearson Correlation & 0,683 & 0,698 & 0,586 & 0,613 & 1 & 0,705 \\
\hline Well-Being & $\mathbf{N}$ & 97 & 93 & 99 & 93 & 99 & 98 \\
\hline F Organisa- & Pearson Correlation & 0,759 & 0,767 & 0,777 & 0,674 & 0,705 & 1 \\
\hline tional & $\mathrm{N}$ & 100 & 97 & 101 & 95 & 98 & 102 \\
\hline
\end{tabular}

All correlations are significant at the 0,001 level (2-tailed).

High correlations (>0.5) amongst all dimensions would suggest that all dimensions share common variance. Owing to limited space, correlations between the subsections are not provided.

Exploring differences between the biographical groups

To determine whether significant differences in scores exist between biographical groupings, t-tests (equality of means - 2tailed) were calculated between the two PDI status groups (white and non-white), as well as between male and female. ANOVA tests were performed between the age groups and between the service tenure groups.

The ANOVA and t-test results are provided in Table 5.

TABLE 5

DIFFERENCES IN BIOGRAPHICAL GROUPINGS

\begin{tabular}{lcccccccc}
\hline & \multicolumn{4}{c}{ ANOVA } & \multicolumn{3}{c}{ T-Tests } \\
\hline Age & \multicolumn{1}{c}{$\begin{array}{c}\text { Years of } \\
\text { service }\end{array}$} & Gender & & $\begin{array}{c}\text { PDI } \\
\text { status }\end{array}$ \\
\hline Dimension & f & Sig. & f & Sig. & t & $\begin{array}{c}\text { Sig } \\
(2 \text { tail })\end{array}$ & t & $\begin{array}{c}\text { Sig } \\
(2 \text { tail })\end{array}$ \\
\hline
\end{tabular}

A1: Mission \& Goals $\quad 2,36 \quad 0,100 \quad 5,092 \quad 0,008 \quad-0,3790,705 \quad 0,785 \quad 0,434$ $\begin{array}{lllllllll}\text { A2: Communication } & 1,507 & 0,227 & 3,652 & 0,030 & -0,828 & 0,409 & -0,916 & 0,362\end{array}$ A3: Planning $\begin{array}{llllllll}0,667 & 0,516 & 4,004 & 0,022 & -0,795 & 0,429 & -0,374 & 0,709\end{array}$

A4: Coordination $\begin{array}{lllllllll}0,690 & 0,504 & 3,377 & 0,008 & 1,679 & 0,096 & 0,392 & 0,694\end{array}$

$\begin{array}{lllllllll}\text { A5: Decision Making } & 0,432 & 0,650 & 1,929 & 0,151 & 0,962 & 0,338 & -2,423 & 0,017\end{array}$ $\begin{array}{lllllllll}\text { A6: Org. clarity } & 1,208 & 0,303 & 1,952 & 0,148 & -0,947 & 0,346 & -1,165 & 0,247\end{array}$ $\begin{array}{lllllllllllll}\text { A7: Perf. Standards } \quad 2,390 & 0,097 & 4,006 & 0,021 & -0,304 & 0,762 & -2,664 & 0,009\end{array}$ $\begin{array}{lllllllllll}\text { A8: Org. support } \quad 4,457 & 0,014 & 5,626 & 0,005 & -0,311 & 0,765 & -1,445 & 0,125\end{array}$ $\begin{array}{lllllllll}\text { A9: Team work } \quad 0,092 & 0,912 & 2,603 & 0,079 & 0,456 & 0,650 & 0,923 & 0,358\end{array}$ $\begin{array}{lllllllllll}\text { A10: Change } \quad 3,503 & 0,034 & 13,827 & 0,000 & 1,270 & 0,207 & -1,455 & 0,149\end{array}$

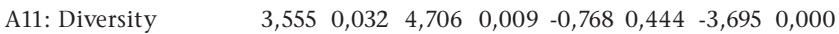
$\begin{array}{lllllllllll}\text { Section A: ORG. } \quad 2,130 & 0,125 & 2,774 & 0,001 & -0,745 & 0,458 & -1,884 & 0,063\end{array}$ CLIMATE

$\begin{array}{lllllllll}\text { B1: Overall satisfctn } \quad 2,391 & 0,097 & 3,468 & 0,035 & -0,510 & 0,611 & -1,093 & 0,277\end{array}$

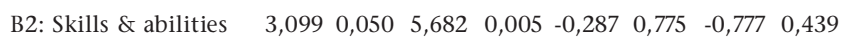
B3: Leadership $\quad 1,133 \quad 0,326 \quad 6,413 \quad 0,002 \quad-0,441 \quad 0,660 \quad-0,852 \quad 0,369$ $\begin{array}{lllllllllllll}\text { B4: Relationships } \quad 1,945 & 0,149 & 1,533 & 0,221 & 0,384 & 0,702 & -0,040 & 0,068\end{array}$ B5: Remuneration $\quad 3,612 \quad 0,031 \quad 2,896 \quad 0,061 \quad 0,715 \quad 0,477 \quad-2,028 \quad 0,045$ $\begin{array}{llllllllll}\text { B6: Perf. Evaluation } \quad 0,311 & 0,734 & 6,560 & 0,002 & -0,727 & 0,496 & -1,854 & 0,067\end{array}$

$\begin{array}{lllllllll}\text { Section B: JOB } & 1,784 & 0,174 & 6,298 & 0,003 & 0,019 & 0,985 & -1,292 & 0,200\end{array}$ SATISFACTION

Section C: Employer 2,514 $\quad 0,086 \quad 8,006 \quad 0,001 \quad-0,810 \quad 0,420 \quad-2,550 \quad 0,012$ of Choice

$\begin{array}{llllllll}\text { D1: Why I came to } \quad 4,806 & 0,010 & 4,395 & 0,015 & -1,495 & 0,183 & -0,764 & 0,447\end{array}$ work here

$\begin{array}{llllllll}\text { D2: Why I continue } \quad 4,058 & 0,020 & 4,758 & 0,011 & -1,549 & 0,125 & -1,480 & 0,142\end{array}$ to work here

$\begin{array}{llllllll}\text { Section D: Propen- } \quad 4,886 & 0,010 & 5,116 & 0,008 & -1,523 & 0,131 & -1,210 & 0,230\end{array}$ sity to stay/leave

$\begin{array}{lllllllll}\text { Section E: Employee } & 0,647 & 0,526 & 8,986 & 0,000 & -2,040 & 0,044 & -0,666 & 0,507\end{array}$ well-being

Section F: Org

$\begin{array}{llllllll}2,433 & 0,093 & 8,337 & 0,000 & -1,640 & 0,104 & -2,251 & 0,027\end{array}$ commitment

T-values and F-values with a significance less than 0,05 indicate a significant difference between groups.

Predicting propensity to stay

Adjusted R-square calculations were performed to establish to what extent one section causes variance in another section. The R-square values are indicated in Figure 3.

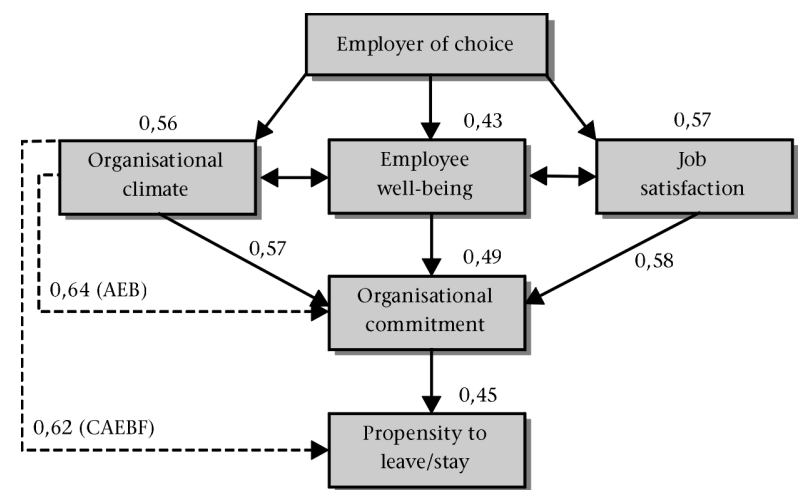

Figure 3: Sources of variance between variables

High R-square values $(>0,5)$ indicate a large amount of variance explained by the respective predictors.

\section{DISCUSSION}

Of the respondents, about $45 \%$ were males and $54 \%$ females, indicating a fairly balanced group. Two thirds of the respondents were white (non-PDI status). This is fairly representative of the current racial composition of the higher income groups at the participating banks - though not of the broader South African demographics.

Regarding the reliability analysis as per Table 3, high levels of reliability $(>0,7)$ are reported on all sections, ranging between 0,739 to 0,959 . The obtained reliability coefficients can be questioned based on the small sample size. Owing to the small sample size the items were parcelled in theoretical dimensions in the first level factor analysis and by intercorrelating sub-scores from these parcels on the second level factor analysis reliabilities were derived. This procedure resulted in reliabilities higher than 0,9 . Three of the eleven subsections of section $A$ are characterised by lower Cronbach's Alpha values. This may be due to the small number of items in each subsection. The correlation analysis indicated strong correlations between all factors, which 
are significant at the 0,01 level (2-tailed). The correlations range between 0,884 and 0,586 .

\section{Predicting the propensity to stay or leave}

The large proportion of variance explained in propensity to stay or leave, as reflected by the adjusted R-square values in Figure 3, indicate a statistically sound model. This study thus confirmed the assumptions in Veldsman's model that the major factors affecting retention are organisational commitment, employer of choice perceptions, organisational climate and employee well-being.

These major factors affecting retention have also been reported in literature as follows:

a) Factors pertaining to organisational climate and culture: As reported in Figure 3, 57\% of the variance in organisational commitment is explained by organisational climate. With reference to the various factors that comprise organisational climate in Table 2, this strong relationship has also been reported by Hay (2002), Lok and Crawford (1999) and Markinor (2003). These studies all reported retention's positive correlation with a clear sense of direction, control over the working environment, un-bureaucratic subcultures, commitment to team, innovative and supportive subcultures.

b) Factors pertaining to job satisfaction: As reported in Figure 3, $58 \%$ of the variance in organisational commitment is explained by job satisfaction. With reference to the various factors that comprise job satisfaction in Table 2, this strong relationship has also been reported by the following researchers: Udo and Tor-Guimaraes (1997) on job satisfaction, job involvement and task characteristics; Taylor (2002), Brewer (1993), Roland et al (1996) and Hay (2002) on a good relationship/satisfaction with immediate supervisor, the employee's commitment to the managerial strategy and managerial processes; Lok and Crawford (1999) and Sigler (1999) on acceptance by co-workers, feedback from manager and the level of professionalism in the workplace; Hay (2002) on skills development, the opportunity to learn new skills and advancement opportunities; Westcott (2003) on the prospect of better pay and better working conditions; Markinor (2003) on fair treatment, care/concern and better communication.

c) Factors pertaining to employee-wellbeing: As reported in Figure 3, 49\% of the variance in organisational commitment is caused by employee well-being. In this regard, Udo and TorGuimaraes (1997) found that role stressors were significant indirect influences on retention.

d) Factors pertaining to employer of choice perceptions: As reported in Figure 3 as well as in Table 4, employer of choice is strongly related to organisational commitment. The dimensions that make up "employer of choice" have been described by Ahlrichs (2000). All these dimensions have been linked to retention in various studies, especially in the studies of Markinor (2003), Hay (2002), Durkin and Bennett (1999) and Udo and Tor-Guimaraes (1997).

\section{Biographical differences}

The other aim of the study was to determine whether differences exist between demographical groupings such as PDI status, gender, service tenure and age pertaining to factors that affect retention. If such differences exist, different retention strategies would be required to address their unique characteristics. This appears to be indeed the case:

\section{PDI status differences}

Several statistical significant differences exist between PDI and non-PDI groups. All differences were rated small to medium effect based on the obtained Eta square values. Previously disadvantaged individuals gave lower scores than whites in Subsection A5 (decision making), Subsection A7, (performance standards), Subsection A11 (diversity), Subsection B5 (remuneration), Section C (employer of choice perceptions) and
Section F (organisational commitment). Could it be that PDIs perceive their appointments to some extent as tokenism, without "real" decision making and that double standards are thus applied in the company? Being sought after in the South African labour market at present, could PDIs be under the impression that they are underpaid? Do they feel that companies are not genuinely valuing diversity? These issues could be investigated in future studies.

This study suggests that the retention of PDIs could be enhanced by achieving the following:

- Improve decision making involvement and awareness of the rationale of decisions in the company.

- Set clear and challenging goals and encourage staff to achieve them. Improve the links between remuneration, recognition and good work.

- Manage diversity more efficiently, value diversity and attend to negative equality perceptions.

- Attend to remuneration concerns (i.e. perceptions of under payment and remuneration fairness issues)

- Improve employer of choice perceptions.

\section{Age differences}

Significant differences, of small to medium effect, based on the obtained Eta square values exist in the following sections: Subsection A8, Organisational Support: Respondents in the 41+ age category gave higher scores than the 31-40 age category. Subsection A 10, Change: Respondents in the 18-30 age category gave higher scores than the 30-40 age category. Subsection A11, Diversity: Respondents in the 18-30 age category gave higher scores than $30-40$ age category. Subsection B5, Remuneration: Respondents in the 41+ age category gave a higher score than the 30-40 age category. Section D, Propensity to leave is higher amongst the respondents in the 31-40 age category than amongst the 18-30 age category.

This study suggests that retention could be enhanced with strategies or interventions which are targeted at the indicated age categories where the identified problems exist. Notably, such problems mostly exist in the 31-40 age category. Could it be that staff in this age category are more prone to unrealistic expectations and thus became frustrated with the lack of opportunities and perceived poor change management? These issues could be investigated by future research.

\section{Years of service differences}

Tenure differences are reported in three categories. The first category is between respondents with 1-3 years service who gave statistically significant higher scores than respondents with 4-9 years service in Sections A (Organisational Climate) and B (Job satisfaction). Within Sections A and B, this difference occurred in following subsections: Subsection A1 (Mission and Goals) Subsection A2 (Communication), Subsection A8 (Organisational Support), Subsection A10 (Change), Subsection A11 (Diversity) and Subsection B3 (Leadership).

The second difference is between respondents with 1-3 years service who gave significant higher scores than respondents with 10+ years service in the following dimensions: Subsection A4 (Coordination and control), Subsection B1 (Overall satisfaction), Subsection B2 (Skills and abilities), Section D (Propensity to stay), Section E (Employee wellbeing) and Section $\mathrm{F}$ (Organisational commitment).

Thirdly, staff with $10^{+}$years service gave higher scores on subsection A7 (Performance standards) than staff with 4-9 years service.

The research clearly indicates that staff with medium to longer tenure is experiencing more problems that impact on retention than staff who joined less than 4 years ago. Could this be indicative of longer tenure staff's inability or unwillingness to deal with the constant change in the workplace? This study thus 
suggests that retention could be enhanced with strategies or interventions which are targeted at medium and longer term tenure groups, in the problem areas indicated above.

\section{Gender differences}

Only one statistically significant difference between male and female was identified. The employee wellbeing (positive feelings or emotions) of females are higher than males. The difference was rated a small effect based on the obtained Eta square coefficient. It can be derived from Table 1 that the majority of the male respondents were white males. Could the current Employment Equity legislation and practices (that reduce the opportunities and options for white males) have a negative effect on the wellbeing of white males? This issue could be investigated in future studies. This study thus suggests that retention amongst males could be enhanced with interventions that increase the wellbeing of males.

\section{Limitations of the study}

Only two banks participated in this study, both with a staff complement of less than 1000. As such the results cannot be assumed to be representative of the either the broader South African banking industry, or the broader South African work force.

\section{Suggestions for future research}

It is suggested that further research should be conducted to determine whether the factors affecting retention of managerial and specialist staff (as identified in this study) would also be applicable in bigger financial institutions, and possibly in other industries than the banking industry.

This study revealed that employees over the age of 30, males, previously disadvantages individuals, as well as individuals with more than 4 years service are the problematic biographical groups in terms of retention. This study has dealt with WHAT the issues are, but not WHY these issues have developed amongst these groups. It is suggested that qualitative studies should be conducted to research the reasons for retention complications amongst these biographical groups.

In this study several suggestions were made to enhance retention amongst the indicated biographical groups where their propensity to leave seemed concerning. A final suggestion for further research would be in the nature of such strategies or interventions as well as how successful these strategies or interventions eventually proved to be.

\section{REFERENCES}

Ahlrichs, N.S. (2000). Competing for talent. Key recruitment and retention strategies for becoming an employer of choice: Palo Alto, CA: Davies-Black Publishing.

Brewer, A. (1993). Managing for employee commitment, Sydney: Longman

Clegg, C.W. (1983). Psychology of employee lateness, absence and turnover. Journal of Applied Psychology, 68 (3), pp 88-101.

Cotton, J.L. \& Tuttle, J.M. (1986). Employee turnover: a metaanalysis and review with implications for research. Academy of Management Review, 11 (3), pp 55-70.
Demby, E.R. (2002). Loyalty may become cool again. Workforce Online. January 2002. Retrieved November 13, 2003, from the World Wide Web: www.workforce.com/archive/feature/ 23/38/78/index.php.

Dibble, S. (1999). Keeping your valuable employees. New York: John Wiley and Sons, Inc.

Durkin, M. \& Bennett, H. (1999), Employee commitment in retail banking, International Journal of Bank Marketing, 17 (3), pp 124-134

Frost, L. (2002, May). Finding the top people. HR Future Magazine, 2001, 1 (3), pp 30-32.

Hay, M. (2002). Strategies for survival in the war of talent. Career Development International, 6 (1), pp 52-55.

Herman, R.E. \& Goya, J.L. (2000). How to become an Employer of Choice. Winchester Virginia: Oakhill Press.

Johnson, M. (2002). Talent Magnet, getting talented people to work for you. London: Prentice Hall.

Lok, P. \& Crawford, J. (1999). The relationship between commitment and organisational culture, subculture, leadership style and job satisfaction in organizational change and development. Leadership and Organisational Development Journal, 20 (1), pp 365-374.

Luthans, F. (1998). Organisational Behaviour ( $8^{\text {th }}$ ed). Singapore: Irwin/ McGraw-Hill.

Markinor. (2003). South African employee relationship survey, September 2003. Retrieved October 1, 2003, from the World Wide Web: http://www.markinor.co.za/ downloads/ERR.doc

Moran, E.T. \& Volkwein, J.F. (1992). The cultural approach to the formation of organisational-climate. Human Relations, 45 (1), pp 19-47.

Roland, T., Rust, G.L., Stewart, H.M. \& Pielack, D. (1996). The satisfaction and retention of front-line employees. International Journal of Service Industry Management, 7 (5), pp 62-80.

Roodt, G. \& Bothma, FC (1997) Die koste van vrywillige, beheerbare arbeidsomset. Tydskrif vir Bedryfsielkunde, 23 (1), 26-30.

Schepers, J.M. (1993). Betroubaarheid van saamgestelde tellings. Journal of Industrial Psychology, 19 (3), pp 1-5.

Sigler, K.J. (1999). Challenges of Employee Retention. Management Research News, 22(10), pp 1-6.

Taylor, C.R. (2002). Focus on Talent. $T+D, 56$ (12), pp. 26-33.

Udo, G.J., Tor-Guimaraes \& M.I. (1997). An investigation of the antecedents of turnover for manufacturing plan managers. International Journal of Operation Management, 19 (9), pp 912-930.

Veldsman, T.H. (2003). Personal communication. Internal research report. CS Holdings.

Westcott, M. (2003). SA companies' workforce are stabilising, survey shows. Business Day 18 February 2003, Retrieved October 1, 2003, from the World Wide Web: http://www. businessday.co.za/Articles/TarkArticle. aspx?ID=701470.

Warr, P. (1990). The measurement of well-being and other aspects of mental health. Journal of Occupational Psychology, 63, pp 193-210

Williams, L.J. and Hazer, J.T. (1986). Antecedents and consequences of satisfaction and commitment in turnover models. Journal of Applied Psychology, 72 (1), pp. 219 -310. 